\title{
RELEVANSI NILAI MODAL INTELEKTUAL (PENDEKATAN RETURN ON ASSETS DAN MARKET CAPITALIZATION METHOD)
}

\author{
Jessy Malinda ${ }^{1)}$, Dyna Rachmawati ${ }^{2)}$ \\ ${ }^{1), 2)}$ Program Studi S1 Akuntansi, Fakultas Bisnis, Universitas Katolik Widya Mandala Surabaya \\ E-mail: jessymalinda@gmail.com
}

Diterima 27 Januari 2020 / Disetujui 29 Agustus 2020

\begin{abstract}
Value relevance is the ability of a value in explaining information about company's valuation. Company valuation has a connection with the investors and their investment decisions. Based on the Resource Based View (RBV) theory, well-managed intellectual capital can generate value added and future competitive advantage for the company. This value added and competitive ability can affect investor's decision to make an investment in the company. This investment decision means the demand for company shares are increasing and along with this increase, the company's market share price also increases. The increase in company's stock price will increase the value of the company.This quantitative research aims to examine and analyze the value relevance of intellectual capital. Intellectual capital in this study measured using the Value Added Intellectual Coefficient $\left(V A I C^{T M}\right)$ method, Intellectual Capital Index (ICI), and through Yahoo Finance's Internet Message Boards (IMBs). The independent variable in this study is intellectual capital, the dependent variable used is firm value, and the control variable is size of the company used in this study. This research samples was selected using purposive sampling method on the companies registered in Kompas 100 for the period of July 2019. Data analysis in this study used multiple linear regression. The results of this study conclude that intellectual capital measured using $V A I C^{T M}$ and through Yahoo Finance IMBs has no value relevance. Whereas intellectual capital which is measured using ICI has value relevance. These results indicate that ICI is the most appropriate proxy for measuring intellectual capital.
\end{abstract}

Keywords: value relevance, intellectual capital, firm value, company size

ABSTRAK: Relevansi nilai merupakan kemampuan suatu nilai dalam menjelaskan informasi mengenai penilaian suatu perusahaan. Penilaian suatu perusahaan memiliki kaitan dengan investor dan keputusan investasinya. Berdasarkan teori Resource Based View (RBV), modal intelektual yang dikelola dengan baik dapat menghasilkan nilai tambah dan keuntungan kompetitif di masa depan bagi perusahaan. Nilai tambah dan kemamppuan kompetitif ini dapat mempengaruhi pengambilan keputusan investor untuk memberikan investasi pada perusahaan. Adanya keputusan investasi pada perusahaan berarti permintaan atas saham perusahaan meningkat dan seiring dengan peningkatan ini, harga pasar saham perusahaan ikut meningkat. Peningkatan pada harga saham perusahaan akan memberikan kenaikan pada nilai perusahaan. Penelitian kuantitatif ini bertujuan untuk menguji dan menganalisis relevansi nilai modal intelektual. Modal intelektual dalam penelitian ini diukur dengan menggunakan metode Value Added Intellectual Coefficient $\left(\mathrm{VAIC}^{\mathrm{TM}}\right.$ ), Intellectual Capital Index (ICI), dan melalui Internet Message Boards (IMBs) Yahoo Finance. Variabel independen dalam penelitian ini adalah modal intelektual, variabel dependen yang digunakan adalah nilai perusahaan, dan variabel kontrol yaitu ukuran perusahaan digunakan dalam penelitian ini. Sampel penelitian dipilih menggunakan metode purposive sampling pada perusahaan yang terdaftar di Kompas 100 periode Juli 2019. Analisis data dalam penelitian ini menggunakan regresi linear berganda.Hasil penelitian ini menyimpulkan bahwa modal intelektual yang diukur menggunakan VAIC ${ }^{\mathrm{TM}}$ dan melalui IMBs Yahoo Finance tidak memiliki relevansi nilai. Sedangkan modal intelektual yang diukur menggunakan ICI memiliki relevansi nilai. Hasil ini menunjukkan bahwa ICI merupakan proksi yang paling tepat untuk digunakan dalam mengukur modal intelektual.

Kata Kunci: relevansi nilai, modal intelektual, nilai perusahaan, ukuran perusahaan 


\section{Pendahuluan}

Pengetahuan merupakan sumber daya penting dalam era globalisasi. Pengetahuan memberikan keunggulan bersaing bagi perusahaan yang memilikinya. Amazon.com merupakan salah satu contoh perusahaan yang mempunyai pengetahuan dalam bisnis toko buku secara daring yang pertama kali di Amerika Serikat dan bahkan dunia pada tahun 1994. Pada saat itu, Amazon.com sudah menerapkan infrastruktur virtual untuk mendukung sistem e-commerce-nya. Hal ini memberikan keunggulan bersaing bagi Amazon.com karena mampu bekerja secara efisien (Dudovsky, 23 Maret 2020). Gojek juga menjadi salah satu contoh perusahaan yang memiliki pengetahuan dan memberikan keunggulan bersaing. Perusahaan ini didirikan dengan motivasi untuk memberikan alternatif solusi kemacetan lalu lintas di Jakarta pada tahun 2010 (gojek.com). Gojek memberikan berbagai layanan teknologi, seperti: paket, makanan, belanja harian dan sebagainya. Berbagai layanan teknologi ini memberikan keunggulan bersaing bagi Gojek (Forddanta, 6 Nopember 2018). Amazon.com dan Gojek adalah contoh perusahaan yang menggunakan pengetahuannya dalam bentuk produk untuk memenuhi kebutuhan pasar. Produk tersebut belum banyak tersedia, sehingga memberikan keunggulan bersaing bagi Amazon.com dan Gojek.

Keunggulan bersaing dapat dicapai oleh perusahaan apabila perusahaan mempunyai sumber daya yang memenuhi karakteristik valuable, rare, inimitability, dan non subsitutable (VRIN). Pengetahuan merupakan sumber daya yang memenuhi karakteristik VRIN. Pengetahuan perusahaan berasal dari individu-individu yang dimilikinya atau disebut dengan human capital (Nonaka, 1991). Pengetahuan tersebut dieksternalisasikan dalam berbagai bentuk antara lain proses bisnis, sistem informasi, dan sebagainya. Ini disebut dengan structural capital. Structural capital ini akan mampu meningkatkan layanan konsumen, sehingga hubungan perusahaan dengan konsumen menjadi dekat. Hal ini memberikan customer capital bagi perusahaan. Human capital, structural capital, dan customer capital merupakan komponen-komponen modal intelektual (Edvinsson, 1997).

Modal intelektual adalah aset tidak berwujud dalam bentuk eksternalisasi pengetahuan sehingga mampu memberikan keunggulan bersaing perusahaan (Chizari, Mehrjardi, Sadrabadi, dan Mehrjardi, 2016). Secara konsep, modal intelektual adalah sumber daya yang mampu memberikan kompetensi inti bagi perusahaan. Konsep ini disebut dengan resource based view (RBV). Konsep ini menjelaskan bahwa sumber daya internal mempunyai peran penting dalam menciptakan nilai perusahaan (Sirojudin dan Nazaruddin, 2014; Ariff, Zijl, dan Islam, 2015). Modal intelektual merupakan salah satu sumber daya tidak berwujud yang dimiliki secara internal dan mampu memberikan nilai tambah bagi perusahaan.

Nilai tambah yang dihasilkan oleh modal intelektual diukur dengan value added intellectual coefficient (VAIC). VAIC $^{\mathrm{TM}}$ dikembangkan oleh Pulic pada tahun 2000. VAIC $^{\mathrm{TM}}$ didasarkan pada konsep pengukuran modal intelektual dengan pendekatan return on assets (ROA). Pendekatan untuk mengukur modal intelektual meliputi return on assets (ROA), market capitalization method (MCM), direct intellectual capital methods (DICM), dan scorecard method (SC Method). Pendekatan ROA merupakan pendekatan yang mengestimasi nilai modal intelektual dengan membagi penghasilan di atas-rata-rata pada biaya modal rata-rata tertimbang perusahaan atau suku bunga. Pendekatan MCM mengukur modal intelektual dengan menghitung perbedaan antara kapitalisasi pasar dan ekuitas pemegang saham perusahaan. Pendekatan DICM menaksirkan nilai aset tidak berwujud melalui identifikasi dan pemberian nilai pada komponen-komponen aset tidak berwujud atau modal intelektual. Pendekatan SC Method menilai modal intelektual dengan mengidentifikasi 
komponen-komponen modal intelektual dan menghasilkan parameter serta indeks yang dilaporkan dalam scorecard atau grafik (Jurczak, 2008; Mohamed, 2017).

Pendekatan untuk mengukur modal intelektual pada penelitian ini menggunakan ROA dan MCM. Pendekatan ROA mengukur modal intelektual dengan metode $\left(\mathrm{VAIC}^{\mathrm{TM}}\right.$ ). Metode $\mathrm{VAIC}^{\mathrm{TM}}$ mengambil data dari laporan keuangan perusahaan. Sumber data laporan keuangan ini tersedia untuk umum sehingga sumber data ini mudah diperoleh baik oleh pengguna internal maupun pengguna eksternal. Metode yang dikembangkan oleh Pulic (2000) ini dinilai sebagai metode yang mudah, namun metode ini juga mendapatkan kritik atas penggunaan laporan keuangan sebagai sumber datanya. Laporan keuangan dianggap sebagai backward-looking karena nilai yang dicatat berasal dari biaya historis bukan harga pasar saat ini atau nilai bagi perusahaan (Brealey, Myers, dan Marcus, 2008:58). Pendekatan MCM mengukur modal intelektual dengan 2 metode, yaitu: pertama, intellectual capital index (ICI) yang dikembangkan oleh McGuire dan Brenner (2015:23). Kedua, pengungkapan modal intelektual pada internet message boards (IMBs) pada Yahoo Finance yang dikembangkan oleh Massaro, dkk (2017). Modal intelektual diukur dengan banyaknya diskusi mengenai emiten tertentu pada IMBs di Yahoo Finance. Kedua metode ini masih jarang digunakan pada penelitianpenelitian sebelumnya untuk mengukur modal intelektual.

Penelitian-penelitian sebelumnya sudah banyak yang menguji relevansi nilai modal intelektual yang diukur dengan $\mathrm{VAIC}^{\mathrm{TM}}$. Namun hasil penelitian-penelitian sebelumnya masih belum konklusif. Penelitian Nuryaman (2015), membuktikan bahwa nilai perusahaan secara positif dipengaruhi oleh VAIC $^{\mathrm{TM}}$. Shella dan Wedari (2016), dalam penelitiannya menemukan bahwa modal intelektual yang diukur menggunakan VAIC ${ }^{\mathrm{TM}}$ berpengaruh positif signifikan dan dapat memberi nilai tambah atau meningkatkan market performance (Tobins'Q). Sedangkan penelitian oleh Lailiyah (2016), yang juga menggunakan $\mathrm{VAIC}^{\mathrm{TM}}$ untuk mengukur modal intelektual, menyimpulkan bahwa modal intelektual memiliki pengaruh negatif pada nilai perusahaan. Lestari dan Sapitri (2016), yang dalam penelitiannya menganalisis pengaruh modal intelektual pada nilai perusahaan, menunjukkan bahwa nilai perusahaan tidak dipengaruhi VAIC (Value Added Intellectual Coefficient). Ini menunjukkan bahwa relevansi nilai VAIC $^{\mathrm{TM}}$ belum konklusif.

Penelitian-penelitian terdahulu yang menguji relevansi nilai ICI masih belum banyak. Rachmawati, Rahayu, dan Wijaya (2018) menguji kemampuan prediksi ICI terhadap harga saham. Hasil penelitiannya membuktikan bahwa ICI mampu memprediksikan harga saham pada satu periode ke depan. Ini mengindikasikan bahwa ICI mempunyai relevansi nilai.

Modal intelektual yang diukur dengan IMBs juga belum banyak diuji oleh penelitian-penelitian sebelumnya. Massaro, dkk (2017) menggunakan IMBs untuk mengukur modal intelektual dengan meneliti diskusi antara investor pengguna web 2.0 melalui Internet Message Boards (IMBs) Yahoo Finance dan TheLion.com sebagai sumber data. Hasil penelitian menyimpulkan bahwa IMBs Yahoo Finance dan TheLion.com mengandung informasi modal intelektual. Hasil-hasil penelitian ini mengindikasikan adanya sumber data selain laporan tahunan perusahaan dalam mengukur modal intelektual.

\section{Identifikasi Masalah}

Berdasarkan latar belakang diatas, maka dapat diidentifikasi masalah dalam penelitian ini yaitu apakah modal intelektual dapat mempengaruhi nilai perusahaan?

\section{Tujuan dan Manfaat}

Penelitian ini bertujuan untuk menguji adanya relevansi nilai modal intelektual. Relevansi nilai adalah seberapa jauh investor menyerap informasi publik sehingga tercermin pada harga saham. Pengujian relevansi nilai merujuk pada 
model yang dikembangkan oleh Feltham dan Ohlson (1985). Modal intelektual yang diukur dengan metode $\mathrm{VAIC}^{\mathrm{TM}}$, ICI dan IMBs diregresikan dengan harga saham sebagai proksi nilai perusahaan.

\section{Pengembangan Hipotesis}

Dalam konsep RBV, perusahaan yang mampu memanfaatkan sumber dayanya dengan baik dapat menciptakan keuntungan kompetitif. Modal intelektual diilustrasikan sebagai sumber daya yang unik, eksklusif, dan tidak mudah ditiru sehingga dapat memberikan keuntungan kompetitif serta nilai tambah bagi perusahaan. Modal intelektual dapat menggambarkan kemampuan internal perusahaan dalam menyusun dan menerapkan strateginya. Kemampuan perusahaan dalam menyusun dan menerapkan strateginya dengan baik akan mempengaruhi kinerja dan nilai perusahaan. Nilai perusahaan dapat digunakan investor dalam mempertimbangkan keputusan investasinya bagi perusahaan. Perusahaan dengan modal intelektual yang lebih besar cenderung memiliki nilai perusahaan yang lebih tinggi, peningkatan pada nilai modal intelektual akan meningkatkan nilai perusahaan pula (Berzkalne dan Zelgalve, 2014; Sirojudin dan Nazaruddin, 2014; Fitriasari dan Sari, 2019).

Dalam penelitiannya, Nuryaman (2015) menggunakan modal intelektual yang diukur dengan metode $\mathrm{VAIC}^{\mathrm{TM}}$ dan nilai perusahaan yang diukur dengan menggunakan Price to Book Value (PBV). Hasil penelitian Nuryaman (2015) menyimpulkan bahwa nilai perusahaan secara positif dipengaruhi oleh modal intelektual. Semakin tinggi modal intelektual maka akan menaikkan nilai perusahaan (Fitriasari dan Sari, 2019). Investor akan menilai sebuah perusahaan lebih tinggi jika modal intelektualnya lebih baik. Dalam Rachmawati dkk. (2018), modal intelektual diukur dengan metode ICI dan nilai perusahaan diukur dengan jumlah nilai pasar ekuitas dengan nilai buku yang dibagi dengan total aset. Penelitian tersebut menyimpulkan bahwa modal intelektual mempunyai kemampuan dalam memprediksi nilai perusahaan. Semakin besar nilai ICI maka semakin tinggi nilai perusahaan di masa yang akan datang. Hal ini dapat berarti modal intelektual dapat menciptakan nilai perusahaan dan mempengaruhi investor dalam memilih keputusan investasinya. Massaro dkk. (2017) mengukur tingkat modal intelektual yang terdapat dalam IMBs Yahoo Finance dan TheLion.com, dalam hasil penelitian menyimpulkan bahwa IMBs Yahoo Finance dan TheLion.com mengandung informasi intelektual. Hal ini mengindikasikan bahwa informasi intelektual juga dapat ditemukan pada media lain selain laporan tahunan perusahaan. Namun, dengan adannya beberapa pendekatan dalam mengukur modal intelektual seperti pendekatan ROA yang datanya lebih bersumber dari laporan keuangan perusahaan, dan pendekatan MCM yang lebih memperhatikan aspek pasar perusahaan seperti harga saham, berpotensi menyebabkan adanya pengaruh yang berbeda antar pendekatan yang digunakan. Suatu nilai dikatakan memiliki relevansi nilai jika nilai tersebut mampu menggambarkan informasi mengenai penilaian suatu perusahaan. Perusahaan yang mempunyai modal intelektual yang tinggi dapat menghasilkan nilai tambah bagi perusahaan dan nilai tambah tersebut dapat mempengaruhi keputusan investasi oleh investor.

\section{$\mathrm{H}_{1}$ : Modal intelektual berpengaruh} terhadap nilai perusahaan.

\section{Metode Penelitian}

Penelitian ini merupakan penelitian kuantitatif dengan hipotesis yang diuji menggunakan regresi linear berganda dengan software SPSS versi 23. Regresi yang digunakan adalah sebagai berikut:

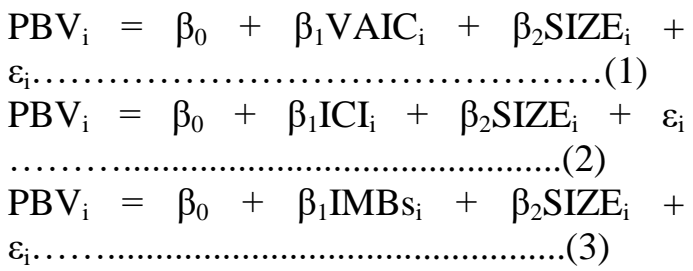


$\mathrm{PBV}_{\mathrm{i}}=\beta_{0}+\beta_{1} \mathrm{VAIC}_{\mathrm{i}}+\beta_{2} \mathrm{ICI}_{\mathrm{i}}+\beta_{3} \mathrm{IMBs}_{\mathrm{i}}+$ $\beta_{4} \mathrm{SIZE}_{\mathrm{i}}+\varepsilon$

Keterangan:

$\mathrm{PBV}_{\mathrm{i}}=$ price to book value perusahaan $\mathrm{i}$ $\mathrm{VAIC}_{\mathrm{i}}=$ modal intelektual perusahaan $\mathrm{i}$ yang diukur dengan VAIC

$\mathrm{ICI}_{\mathrm{i}}=$ modal intelektual perusahaan $\mathrm{i}$ yang diukur dengan metode ICI

$\mathrm{IMBs}_{\mathrm{i}}=$ modal intelektual perusahaan $\mathrm{i}$ yang diukur dengan metode IMBs

$\mathrm{SIZE}_{\mathrm{i}}=$ ukuran perusahaan perusahaan $\mathrm{i}$

\section{Subjek Penelitian}

Populasi dalam penelitian ini adalah seluruh perusahaan yang terdaftar di Kompas100 periode Juli 2019. Periode Juli 2019 merupakan periode terbaru dalam daftar saat penelitian ini dilakukan. Sampel diambil dengan teknik purposive sampling dengan kriteria, perusahaan memiliki data yang dibutuhkan selama tahun 2018.

\section{Pengembangan Instrumen}

Variabel dependen penelitian ini adalah nilai perusahaan. Nilai perusahaan diterangkan sebagai penilaian investor atas keadaan perusahaan pada saat ini maupun di masa depan (Brealey, Myers, dan Marcus, 2008:59). Pengukuran nilai perusahaan menggunakan Price to Book Value (PBV), yang dihitung dengan (Rachmawati dan Susilawati, 2018):

PBV = (Harga Pasar Saham) / (Nilai Buku per Lembar Saham)

Harga saham yang digunakan adalah harga penutupan saham per tanggal 30 April 2019. Nilai buku per lembar saham adalah perbandingan total ekuitas perusahaan dengan jumlah lembar saham beredar.

Variabel independen penelitian ini adalah modal intelektual. Modal intelektual merupakan aset tidak berwujud perusahaan seperti pengetahuan, informasi, pengalaman yang dimiliki sumber daya manusia dan perusahaan (Stewart, 1997; dalam Nuryaman, 2015). Pada penelitian ini, modal intelektual diukur dengan menggunakan:
1. Pendekatan Return on Assets (ROA) metode Value Added Intellectual Coefficient $\left(\mathrm{VAIC}^{\mathrm{TM}}\right)$. Pengukuran modal intelektual dengan metode $\mathrm{VAIC}^{\mathrm{TM}}$ dihitung berdasarkan model Pulic (2000):

Value Added Capital Employeed - VACA

$\mathrm{VA}=\mathrm{OUT}-\mathrm{IN}$

$\mathrm{VACA}=\mathrm{VA} / \mathrm{CE}$

Value Added Human Capital - VAHU

$\mathrm{VAHU}=\mathrm{VA} / \mathrm{HC}$

Structural Capital Value Added - STVA

$\mathrm{SC}=\mathrm{VA}-\mathrm{HC}$

$\mathrm{STVA}=\mathrm{VA} / \mathrm{SC}$

Keterangan:

Output $($ OUT $)=$ total penjualan dan pendapatan lain

Input $(\mathrm{IN})=$ beban dan biaya-biaya (selain beban karyawan)

Value Added $(\mathrm{VA})=$ selisih antara output dan input

Capital Employed $(\mathrm{CE})=$ dana yang tersedia (ekuitas akhir)

Human Capital $(\mathrm{HC})=$ beban karyawan

Structural Capital $(\mathrm{SC})=$ modal struktural

Value Added Intellectual Coefficient $\mathrm{VAIC}^{\mathrm{TM}}$

$\mathrm{VAIC}^{\mathrm{TM}}=\mathrm{VACA}+\mathrm{VAHU}+$ STVA.............................(11)

2. Market Capitalization Methods (MCM) yaitu dengan metode Intellectual Capital Index (ICI). Modal intelektual yang diukur menggunakan metode ICI dihitung dengan merujuk pada penelitian Rachmawati, Rahayu, dan Wijaya (2018):

(Intangible assets $($ on books $)+$ Goodwill + (Enterprise Value - Book Value)) / (Enterprise Value).

Book Value

Shareholder's equity + Net Debt (yaitu, Debt - Cash and Marketable Securities) 
Enterprise Value

(Market share price $\mathrm{x}$ shares issued and outstanding)

Net

Debt

3. Market Capitalization Methods (MCM) dengan Internet Message Boards (IMBs) melalui website Yahoo Finance. Pengukuran modal intelektual dengan IMBs melalui Yahoo Finance diukur berdasarkan Massaro, Dumay, dan Bagnoli (2017), yaitu dengan menghitung jumlah komentar dan reply yang diunggah selama tahun 2018 dalam menu "conversation" halaman perusahaan yang terdaftar di Kompas100 periode Juli 2019 di website Yahoo Finance. Komentar dan reply mengandung informasi mengenai perusahaan tersebut, contoh seperti pada halaman perusahaan PT. Telekomunikasi Indonesia Tbk terdapat komentar bahwa, "perusahaan ini membayarkan dividen yang baik" dan reply bahwa, "perusahaan ini membayarkan dividennya secara tahunan".

Penelitian ini menggunakan variabel kontrol yaitu ukuran perusahaan. Ukuran perusahaan merupakan nilai total aset suatu perusahaan yang menggambarkan besar atau kecilnya perusahaan tersebut (Sujoko dan Soebiataro, 2007). Ukuran perusahaan diproksikan dengan total aset perusahaan. Ukuran perusahaan diukur dengan (Pamungkas dan Puspaningsih, 2013):

SIZE $=\log ($ Total assets $)$.

Data dalam satuan mata uang dolar dikonversikan menjadi satuan mata uang rupiah dengan menggunakan kurs tengah BI pada tanggal 30 Desember 2018 yaitu sebesar Rp. 14.481.

\section{Hasil Dan Pembahasan}

\section{Statistik Deskriptif}

Variabel-variabel yang dipakai pada penelitian ini adalah nilai perusahaan (PBV), modal intelektual yang dihitung dengan 3 pendekatan yaitu Value Added Intellectual Coefficient (VAIC); Intellectual Capital Index (ICI); dan Internet Message Boards (IMBs), serta ukuran perusahaan
(SIZE). Data statistik deskriptif terdapat dalam Tabel 1.

Tabel 1. Statistik Deskriptif

\begin{tabular}{lrrrrr}
\hline $\begin{array}{c}\text { Varia } \\
\text { bel }\end{array}$ & N & $\begin{array}{c}\text { Mini } \\
\text { mum }\end{array}$ & $\begin{array}{r}\text { Maxi } \\
\text { mum }\end{array}$ & $\begin{array}{c}\text { Mea } \\
n\end{array}$ & $\begin{array}{c}\text { Std. } \\
\text { Devia } \\
\text { tion }\end{array}$ \\
\hline PBV & 1 & 0,172 & 45,81 & 2,66 & 4,966 \\
& 0 & & 1 & 6 & \\
& 0 & & & & \\
\hline VAI & 1 & - & 18,73 & 5,01 & 3,642 \\
C & 0 & 20,23 & 5 & 6 & \\
& 0 & 2 & & & \\
\hline ICI & 1 & - & 0,948 & 0,20 & 0,458 \\
& 0 & 1,796 & & 9 & \\
& 0 & & & & \\
\hline IMB & 1 & 0,000 & 7,000 & 0,21 & 0,880 \\
s & 0 & & & 0 & \\
& 0 & & & & \\
\hline SIZE & 1 & 11,88 & 15,11 & 13,4 & 0,612 \\
& 0 & 0 & 3 & 42 & \\
& 0 & & & &
\end{tabular}

Sumber: Data diolah (2019)

Tabel 1 menunjukkan nilai rata-rata variabel PBV adalah sebesar 2,666. Hal ini menerangkan bahwa rata-rata perusahaan sampel dalam penelitian ini memiliki ratarata nilai Price to Book Value sebesar 2,666. Nilai minimum PBV adalah sebesar 0,172 yang dimiliki MNC Investama Tbk (BHIT), dan nilai maksimum 45,811 dimiliki Unilever Indonesia Tbk (UNVR). Standar deviasi PBV adalah sebesar 4,966 yang menunjukkan selisih perbedaan nilai PBV tiap perusahaan sampel.

Pada Tabel 1 ditunjukkan bahwa nilai rata-rata VAIC adalah sebesar 5,016. Hal ini berarti rata-rata perusahaan sampel dalam penelitian ini memiliki efisiensi atas nilai tambah yang berasal dari pemanfaatan modal intelektual sebesar 5,016. Nilai minimum variabel VAIC adalah sebesar 20,232 yang dimiliki Garuda Indonesia (Persero) Tbk. (GIAA), dan nilai maksimum VAIC adalah 18,735 yang dimiliki Gajah Tunggal Tbk (GJTL). VAIC 
mempunyai standar deviasi sebesar 3,642 yang menunjukkan selisih nilai efisiensi modal intelektual tiap perusahaan sampel. Dalam Tabel 1 nilai rata-rata variabel ICI adalah sebesar 0,209. Hal ini memperlihatkan bahwa rata-rata perusahaan sampel dalam penelitian ini mempunyai nilai aset intelektual sebesar 0,209. ICI mempunyai nilai minimum sebesar $-1,796$ yang dimiliki Bank BRIsyariah Tbk (BRIS), dan nilai maksimum sebesar 0,948 yang dimiliki Unilever Indonesia Tbk (UNVR). Selisih nilai modal intelektual tiap perusahaan sampel ditunjukkan oleh standar deviasi sebesar 0,458. Tabel 1 menunjukkan nilai rata-rata IMBs yaitu 0,210 yang mengindikasikan bahwa ratarata perusahaan sampel pada penelitian ini memiliki jumlah komentar dan reply sebanyak 0,202 . Nilai minimum variabel IMBs yaitu sebesar 0,000. Nilai maksimum
IMBs sebesar 7,000 dimiliki oleh Telekomunikasi Indonesia (Persero) Tbk (TLKM). Standar deviasi variabel IMBs adalah sebesar 0,880 yang menunjukkan besarnya perbedaan jumlah komentar dan reply tiap perusahaan sampel.

SIZE berdasarkan Tabel 1 mempunyai nilai rata-rata sebesar 13,442 . Hal ini menerangkan bahwa perusahaan sampel memiliki rata-rata ukuran perusahaan dengan total aset sebesar 13,442 . SIZE mempunyai nilai minimum sebesar 11,880 yang dimiliki Buyung Poetra Sembada Tbk (HOKI). Nilai maksimum variabel SIZE adalah 15,113 yang dimiliki Bank Rakyat Indonesia (Persero) Tbk (BBRI). Standar deviasi SIZE adalah sebesar 0,612 yang menunjukkan perbedaan ukuran perusahaan tiap perusahaan sampel.

\section{Hasil Analisis Data}

Tabel 2. Hasil Uji Normalitas

\begin{tabular}{|c|c|c|}
\hline \multirow{2}{*}{ Keterangan } & Unstandardized Residual & \multirow{2}{*}{ Kesimpulan } \\
\hline & Monte Carlo Sign. (2 tailed) Upper Bound & \\
\hline Persamaan 1 & 0,608 & Normal \\
\hline Persamaan 2 & 0,030 & Tidak Normal \\
\hline Persamaan 3 & 0,861 & Normal \\
\hline Persamaan 4 & 0,063 & Normal \\
\hline
\end{tabular}

Sumber: Data diolah (2019)

Tabel 2 di atas menunjukkan bahwa persamaan 2 mempunyai tingkat siginifikansi kurang dari 0,05. Namun, data residual variabel dependen dan independen pada persamaan 2 sudah terdistribusi normal, data ini dapat dilihat pada Tabel 2.1. Distribusi nilai residual persamaan 1 , persamaan 3, dan persamaan 4 normal setelah melakukan transformasi terhadap variabel PBV. Tingkat signifikansi dari uji Kolmogorov-Smirnov pada unstandardized residual menunjukkan angka > 0,05 yang berarti data residual sudah terdistribusi secara normal.

Tabel 2.1. Hasil Uji Normalitas Persamaan 2

\begin{tabular}{lllccc}
\hline & Keterangan & & PBV & ICI & SIZE \\
\hline Monte Carlo & 95\% Confidence & Upper & 0,657 & 0,232 & 0,771 \\
Sig. (2-tailed) & Interval & Bound & & &
\end{tabular}

Sumber: Data diolah 2019 
Tabel 3. Hasil Uji Heteroskedastisitas

\begin{tabular}{lcc}
\hline Keterangan & Sig. & Kesimpulan \\
\hline Persamaan 1 & 0,300 & Tidak terjadi heteroskedastisitas \\
\hline Persamaan 2 & 0,130 & Tidak terjadi heteroskedastisitas \\
\hline Persamaan 3 & 0,752 & Tidak terjadi heteroskedastisitas \\
\hline Persamaan 4 & 0,154 & Tidak terjadi heteroskedastisitas \\
\hline
\end{tabular}

Sumber: Data diolah (2019)

Tabel 3 di atas menunjukkan bahwa tidak terjadi heteroskedastisitas dimana tingkat signifikasnsi $>0,05$. Suatu model regresi adalah baik jika tidak terjadi heteroskedatisitas di dalamnya.

Tabel 4. Hasil Uji Multikolinieritas

\begin{tabular}{cccc}
\hline Variabel & Tolerance & VIF & Kesimpulan \\
\hline & \multicolumn{3}{c}{ Persamaan 1 } \\
\hline VAIC & 0,966 & 1,035 & Tidak terjadi multikolinieritas \\
\hline SIZE & 0,966 & 1,035 & Tidak terjadi multikolinieritas \\
\hline ICI & 0,961 & 1,040 & Tidak terjadi multikolinieritas \\
\hline SIZE & 0,961 & 1,040 & Tidak terjadi multikolinieritas \\
\hline IMBs & 1,000 & 1,000 & Tidak terjadi multikolinieritas \\
\hline SIZE & 1,000 & 1,000 & Tidak terjadi multikolinieritas \\
\hline & & Persamaan 4 \\
\hline VAIC & 0,963 & 1,038 & Tidak terjadi multikolinieritas \\
\hline ICI & 0,958 & 1,044 & Tidak terjadi multikolinieritas \\
\hline IMBs & 0,997 & 1,003 & Tidak terjadi multikolinieritas \\
\hline SIZE & 0,927 & 1,079 & Tidak terjadi multikolinieritas
\end{tabular}

Sumber: Data diolah (2019)

Tabel 4 menunjukkan bahwa tidak adanya korelasi antar variabel independen yang tampak dari nilai tolerance $>0,10$ atau nilai VIF < 10, hal ini berarti model regresi yang digunakan adalah baik.
Tabel 5 memperlihatkan bahwa nilai signifikansi $\leq 0,05$ yang berarti model regresi persamaan 1, persamaan 2, persamaan 3 , dan persamaan 4 adalah layak. 
Tabel 5. Hasil Uji Model

\begin{tabular}{lccl}
\hline Keterangan & $\mathrm{R}^{2}$ & F Sig. & Kesimpulan \\
\hline Persamaan 1 & 0,067 & 0,034 & Model Fit \\
\hline Persamaan 2 & 0,730 & 0,000 & Model Fit \\
\hline Persamaan 3 & 0,066 & 0,036 & Model Fit \\
\hline Persamaan 4 & 0,735 & 0,000 & Model Fit \\
\hline
\end{tabular}

Sumber: Data diolah (2019)

Tabel 6. Hasil Uji Hipotesis

\begin{tabular}{lcccccccc}
\hline Variabel & \multicolumn{2}{c}{ Persamaan 1 } & \multicolumn{2}{c}{ Persamaan 2 } & \multicolumn{2}{c}{ Persamaan 3 } & \multicolumn{2}{c}{ Persamaan 4 } \\
\cline { 2 - 9 } & $\mathrm{B}$ & Sig. & $\beta$ & Sig. & $\beta$ & Sig. & $\beta$ & Sig. \\
\hline VAIC & 0,004 & 0,728 & & & & & 0,008 & 0,204 \\
\hline ICI & & & 0,730 & 0,000 & & & 0,734 & 0,000 \\
\hline IMBs & & & & & 0,005 & 0,910 & $-0,010$ & 0,690 \\
\hline SIZE & $-0,165$ & 0,014 & $-0,062$ & 0,085 & $-0,169$ & 0,010 & $-0,053$ & 0,148 \\
\hline Konstanta & 2,392 & 0,009 & 0,871 & 0,071 & 2,467 & 0,005 & 0,714 & 0,151 \\
\hline
\end{tabular}

Sumber: Data diolah (2019)

Tabel 6 menunjukkan VAIC memiliki nilai signifikansi sebesar 0,728 (persamaan 1) dan 0,204 (persamaan 4) yang lebih besar dari 0,05 sehingga modal intelektual yang diukur dengan $\mathrm{VAIC}^{\mathrm{TM}}$ tidak berpengaruh signifikan terhadap nilai perusahaan. Nilai koefisien regresi $(\beta)$ sebesar 0,004 (persamaan 1) dan 0,008 (persamaan 4) menerangkan bahwa variabel VAIC berpengaruh positif terhadap nilai perusahaan. Nilai $\beta$ menandakan setiap kenaikan 1 satuan VAIC akan meningkatkan nilai PBV sebesar 0,004 (persamaan 1) dan 0,008 (persamaan 4). Hal ini membuktikan bahwa hipotesis modal intelektual memiliki relevansi nilai ditolak.

Tabel 6 menunjukkan ICI mempunyai nilai signifikansi sebesar 0,000 pada persamaan 2 dan 4, yang dimana nilai ini kurang dari 0,05 sehingga modal intelektual yang diukur dengan ICI berpengaruh signifikan terhadap nilai perusahaan. Nilai koefisien regresi $(\beta)$ sebesar 0,730 (persamaan 2) dan 0,734 (persamaan 4) menerangkan bahwa variabel ICI berpengaruh positif terhadap nilai perusahaan. Nilai $\beta$ menandakan setiap kenaikan 1 satuan ICI akan meningkatkan nilai PBV sebesar 0,730 (persamaan 2) dan 0,734 (persamaan 4). Hal ini membuktikan bahwa hipotesis modal intelektual memiliki relevansi nilai diterima.

Tabel 6 menunjukkan IMBs memiliki nilai signifikansi sebesar 0,910 (persamaan 3) dan 0,690 (persamaan 4) yang lebih besar dari 0,05 sehingga modal intelektual yang diukur dengan IMBs tidak berpengaruh signifikan terhadap nilai perusahaan. Nilai koefisien regresi $(\beta)$ sebesar 0,005 (persamaan 3) dan $-0,010$ (persamaan 4) menerangkan bahwa variabel 
IMBs berpengaruh positif (persamaan 3) dan berpengaruh negatif (persamaan 4) terhadap nilai perusahaan. Nilai $\beta$ menandakan setiap kenaikan 1 satuan ICI akan meningkatkan nilai PBV sebesar 0,005 (persamaan 3) dan menurunkan 0,010 (persamaan 4). Hal ini membuktikan bahwa hipotesis modal intelektual memiliki relevansi nilai ditolak.

Tabel 6 menunjukkan SIZE mempunyai nilai signifikansi sebesar 0,014 (persamaan 1) dan 0,010 (persamaan 3), yang berarti ukuran perusahaan berpengaruh signifikan terhadap nilai perusahaan karena mempunyai nilai kurang dari 0,05. Sedangkan nilai signifikansi sebesar 0,085 (persamaan 2) dan 0,148 (persamaan 4) memiliki arti ukuran perusahaan tidak berpengaruh signifikan terhadap nilai perusahaan karena nilainya lebih dari 0,05 . Nilai koefisien regresi $(\beta)$ sebesar -0,165 (persamaan 1), $-0,062$ (persamaan 2), -0,169 (persamaan 3), dan 0,053 (persamaan 4) menerangkan bahwa ukuran perusahaan berpengaruh negatif terhadap nilai perusahaan.

\section{Pembahasan}

Hasil penelitian ini menunjukkan bahwa modal intelektual yang diukur dengan $\mathrm{VAIC}^{\mathrm{TM}}$ tidak memiliki relevansi nilai. Hal ini dapat menerangkan bahwa investor tidak terlalu memahami dan mempertimbangkan besarnya nilai tambah yang dikontribusikan oleh modal intelektual perusahaan dalam mengambil keputusan investasinya. Hasil ini membuktikan bahwa teori Resource Based View (RBV) tidak terkonfirmasi, dimana teori RBV menjabarkan bahwa perusahaan yang dapat mengendalikan modal intelektualnya dengan baik bisa membentuk nilai bagi perusahaan sehingga nilai perusahaan pun meningkat. Hasil ini sejalan dengan penelitian oleh Lestari dan Sapitri (2016) yang menyimpulkan bahwa modal intelektual tidak berpengaruh terhadap nilai perusahaan. Hal ini menunjukkan bahwa penggunaaan pendekatan ROA dengan metode VAIC $^{\text {TM }}$ dalam mengukur modal intelektual masih belum tepat. Hasil ini tidak sejalan dengan penelitian oleh
Nuryaman (2015) yang menyimpulkan bahwa nilai perusahaan secara positif dipengaruhi oleh modal intelektual. Berzkalne dan Zelgalve (2014) menemukan bahwa kenaikan pada modal intelektual seharusnya meningkatkan nilai perusahaan.

Hasil penelitian ini menunjukkan bahwa modal intelektual yang diukur dengan ICI memiliki relevansi nilai. Hasil penelitian ini juga menunjukkan bahwa ICI memiliki pengaruh yang paling besar dibandingkan VAIC dan IMBs terhadap nilai perusahaan. Hal ini ditunjukkan oleh koefisien $\beta$ ICI yang memiliki nilai besar dalam persamaan 4 . Hal ini juga dapat berarti bahwa pendekatan pasar dengan metode ICI merupakan proksi yang paling tepat untuk mengukur modal intelektual karena investor mudah memahami komponen harga pasar saham yang digunakan dalam menghitung ICI. Harga pasar saham merupakan salah satu aspek yang paling diperhatikan oleh investor karena harga pasar saham dapat menggambarkan kondisi suatu perusahaan dan mempengaruhi keputusan investasi oleh investor. Hasil ini sejalan dengan penelitian oleh Rachmawati, Rahayu, dan Wijaya (2018) yang menyimpulkan bahwa modal intelektual memiliki kemampuan dalam memprediksi nilai perusahaan. Semakin besar nilai ICI maka semakin tinggi nilai perusahaan di masa yang akan datang. Hal ini dapat berarti modal intelektual dapat menciptakan nilai perusahaan dan mempengaruhi investor dalam memilih keputusan investasinya. Keputusan untuk berinvestasi dalam perusahaan ini berarti permintaan atas saham perusahaan bertambah dan kenaikan harga saham akan terjadi. Adanya peningkatan pada harga saham ini akan meningkatkan nilai perusahaan pula.

Hasil penelitian ini menunjukkan bahwa variabel modal intelektual yang diukur dengan IMBs tidak memiliki relevansi nilai. Hal ini menjelaskan bahwa investor tidak terlalu memahami dan menggunakan informasi yang terdapat dalam IMBs Yahoo Finance untuk mengambil keputusan investasinya, sehingga tidak memberikan pengaruh pada 
harga saham dan nilai perusahaan. Hasil ini juga dapat mengindikasikan bahwa IMBs Yahoo Finance tidak memiliki informasi intelektual yang dibutuhkan dalam mengambil keputusan investasi oleh investor. Hasil ini tidak sejalan dengan penelitian oleh Massaro, Dumay, dan Bagnoli (2017) yang menyimpulkan bahwa IMBs Yahoo Finance dan TheLion.com mengandung informasi intelektual. Penelitian tersebut mengindikasikan bahwa informasi intelektual juga dapat ditemukan pada media lain selain laporan tahunan perusahaan. Pengungkapan modal intelektual yang dilakukan oleh investor melalui IMBs dapat memberikan keuntungan tersendiri bagi perusahaan. Keputusan investasi oleh investor satu dapat mempengaruhi keputusan investasi investor lainnya. Hal ini akan menambah permintaan saham perusahaan sehingga harga saham perusahaan mengalami peningkatan dan akan menaikkan nilai perusahaan.

Pengaruh berbeda yang ditunjukkan hasil penelitian ini diindikasikan pada perbedaan komponen dalam perhitungan modal intelektual tiap metode. Metode VAIC $^{\mathrm{TM}}$ menggunakan komponenkomponen laporan keuangan seperti beban, ekuitas, dan modal perusahaan. ICI menggunakan data pasar perusahaan seperti harga saham perusahaan. Sedangkan metode IMBs meneliti diskusi mengenai perusahaan pada Yahoo Finance.

\section{Pengaruh ukuran perusahaan terhadap nilai perusahaan}

Hasil penelitian ini menunjukkan bahwa ukuran perusahaan memiliki pengaruh negatif terhadap nilai perusahaan (persamaan 1 dan 3). Hal ini menjelaskan bahwa ukuran perusahaan memiliki keterkaitan dengan nilai perusahaan. Namun dalam persamaan 2 dan 4, hasil menunjukkan ukuran perusahaan tidak berpengaruh terhadap nilai perusahaan yang menjelaskan bahwa diantara ukuran perusahaan dan nilai perusahaan tidak terdapat keterkaitan. Berdasarkan hasil pengujian, ukuran perusahaan mempunyai pengaruh negatif terhadap nilai perusahaan, hal ini menerangkan bahwa besar atau kecilnya suatu perusahaan tidak menentukan besarnya nilai perusahaan tersebut. Hal ini dapat menandakan bahwa investor tidak mempertimbangakan ukuran perusahaan dalam mengambil keputusan investasinya. Hasil ini sejalan dengan hasil penelitian Dewi dan Sudiartha (2017) dimana ukuran perusahaan tidak berpengaruh terhadap nilai perusahaan. Besar kecilnya perusahaan bukan merupakan faktor yang mengakibatikan terjadinya perubahan nilai perusahaan. Berlawanan dengan hasil-hasil tersebut, Pratama dan Wiksuana (2016) menyimpulkan bahwa ukuran perusahaan berpengaruh positif terhadap nilai perusahaan. Perusahaan besar (kecil) mempunyai nilai perusahaan tinggi (rendah).

\section{Simpulan}

Kesimpulan dari hasil pengujian, pembahasan dan analisis pada penelitian ini adalah sebagai berikut:

1. Modal intelektual yang diukur dengan menggunakan Value Added Intelectual Coefficient $\left(\mathrm{VAIC}^{\mathrm{TM}}\right.$ ) tidak memiliki relevansi nilai. Variabel ini tidak memiliki pengaruh pada nilai perusahaan. Hal ini berarti, investor tidak terlalu mengerti dan memperhatikan nilai tambah yang dikontribusikan modal intelektual dalam mengambil keputusan. Sehingga, besarnya nilai modal intelektual belum tentu akan menambah nilai perusahaan.

2. Modal intelektual yang diukur dengan menggunakan Intellectual Capital Index (ICI) memiliki relevansi nilai. Variabel ini memiliki pengaruh positif pada nilai perusahaan. Hal ini berarti investor dapat memahami serta mempertimbangkan modal intelektual dalam pengambilan keputusannya. Sehingga, meningkatnya modal intelektual juga dapat meningkatkan nilai perusahaan.

3. Modal intelektual yang diukur dengan melalui Internet Message Boards (IMBs) Yahoo Finance tidak memiliki relevansi nilai. Variabel ini tidak memiliki pengaruh pada nilai 
perusahaan. Hal ini menunjukkan bahwa IMBs Yahoo Finance tidak memiliki informasi modal intelektual yang dapat dipahami maupun mempengaruhi keputusan investor. Sehingga, besarnya modal intelektual tidak dapat mempengaruhi nilai perusahaan.

Proksi yang paling tepat untuk digunakan dalam mengukur modal intelektual adalah pendekatan pasar dengan metode Intellectual Capital Index (ICI). Berdasarkan pengujian yang telah dilakukan, modal intelektual yang diukur menggunakan ICI memiliki pengaruh positif dan signifikan terhadap nilai perusahaan. Hal ini menunjukkan bahwa ICI merupakan proksi yang tepat bagi modal intelektual karena ICI dapat merepresentasikan nilai perusahaan melalui harga saham pasar perusahaan.

\section{Daftar Pustaka}

Ariff, A. H. M., Zijl, T. van, dan Islam, A. (2015). Intellectual Capital and Market Performance: The Case of Multinational R\&D Firms in The U.S. Proceedings of the Asia Pacific Conference on Business and Social Sciences 2015 Kuala Lumpur (in Partnership with The Journal of Developing Areas), 673-681. https://doi.org/10.1353/jda.2016.0052

Berzkalne, I., dan Zelgalve, E. (2014). Intellectual Capital and Company Value. Procedia - Social and Behavioral Sciences, $\quad 110, \quad 887-896$. https://doi.org/10.1016/j.sbspro.2013.12. 934

Brealey, R. A., Myers, S. C., dan Marcus, A. J. (2008). Dasar-Dasar Manajemen Perusahaan (edisi ke-5). Jakarta: Erlangga.

Brigham, E. F., dan Houston, J. F. (2011). Dasar-Dasar Manajemen Keuangan (edisi ke-11). Jakarta: Salemba Empat.

Chizari, M. hosein, Mehrjardi, R. Z., Sadrabadi, M. M., dan Mehrjardi, F. K. (2016). The Impact of Intellectual Capitals of Pharmaceutical Companies Listed in Tehran Stock Exchange on Their Market Performance. Procedia
Economics and Finance, 36(16), 291300 . https://doi.org/10.1016/s22125671(16)30040-5

Dewi, D. A. I. D., dan Sudiartha, G. M. (2017). Pengaruh Profitabilitas, Ukuran Perusahaan, dan Pertumbuhan Aset Terhadap Struktur Modal dan Nilai Perusahaan. E-Jurnal Manajemen Universitas Udayana, 6(4), 2222-2252.

Dudovsky, D. (2020). Amazon Business Strategy: Cost Leadership and Customer Centricity. 23 Maret 2020. https://researchmethodology.net/amazon-businessstrategy-benefiting-cost-leadershipdiversification/

Edvinsson, L. (1997). Developing Intellectual Capital at Skandia. Long Range Planning. Vol. 30, No. 30, 366373

Feltham, G., dan J. Ohlson. (1995). Valuation and Clean Surplus Accounting for Operating and Financial Activities. Contemporary Accounting Research, Vol 11 (2), 689-731

Fitriasari, A. D., dan Sari, M. M. R. (2019). Pengaruh Intellectual Capital pada Nilai Perusahaan dengan Kinerja Keuangan sebagai Variabel Intervening. E-Jurnal Akuntansi Universitas Udayana, 26(3), 17171740.

Forddanta, D.H. (2018). Ini Keunggulan Gojek dengan Pesaingnya. 6 Nopember 2018.

https://industri.kontan.co.id/news/inikeunggulan-gojek-dengan-pesaingnya

Hirdinis M. (2019). Capital Structure and Firm Size on Firm Value Moderated by Profitability. International Journal of Economics and Business Administration, VII (1), 174-191.

Jurczak, J. (2008). Intellectual Capital Measurement. Institute of Organization and Managment in Industry, 1(1), 3745. https://doi.org/10.4018/978-1-52252255-3.ch438

Lailiyah, M. (2016). Pengaruh Modal Intelektual dan Pengungkapannya Terhadap Nilai Perusahaan. STIE Perbanas, 1-14. 
Lestari, N., dan Sapitri, R. C. (2016). Pengaruh Intellectual Capital Terhadap Nilai Perusahaan. Jurnal Akuntansi, Ekonomi Dan Manajemen Bisnis, 4(1), $28-33$.

Massaro, M., Dumay, J., dan Bagnoli, C. (2017). When The Investors Speak: Intellectual Capital Disclosure and The Web 2.0. Management Decision, 55(9), 1888-1904. https://doi.org/10.1108/MD10-2016-0699

McGuire, T., dan L. Brenner. (2015). Talent Valuation: Accelerate Market Capitalization through Your Most Important Asset. Upple Sadle River

Mohamed, I. A. H. (2017). Methods of Measuring Intellectual Capital and The Efficiency of Investment It: Advantages \& Disadvantages. Analytical Comparative Study. Imperial Journal of Interdisciplinary Research (IJIR), 3(2), 1083-1092

Nonaka, I. (1991). The Knowledge Creating Company. Harvard Business Review, Nopember-Desember 1991

Nuryaman. (2015). The Influence of Intellectual Capital on The Firm's Value with The Financial Performance as Intervening Variable. Procedia - Social and Behavioral Sciences, 211(September), 292-298. https://doi.org/10.1016/j.sbspro.2015.11. $\underline{037}$

Pamungkas, H. S., dan Puspaningsih, A. (2013). Pengaruh Keputusan Investasi, Keputusan Pendanaan, Kebijakan Dividen dan Ukuran Perusahaan Terhadap Nilai Perusahaan. Jurnal Akuntansi \& Auditing Indonesia, 17(2), 155-165.

https://doi.org/10.20885/jaai.vol17.iss2.a rt6

Pratama, I. G. B. A., dan Wiksuana, I. G. B. (2016). Pengaruh Ukuran Perusahaan dan Leverage Terhadap Nilai Perusahaan dengan Provitabilitas sebagai Variabel Mediasi. E-Jurnal Manajemen Universitas Udayana, 5(2), 1338-1367.

https://doi.org/10.24843/ejmunud.2019. v08.i05.p16
Pulic, A. (2000). VAIC ${ }^{\mathrm{TM}}$ - An Accounting Tool for Intellectual Capital Management. International Journal Technology Management, 20(5/6/7/8), 702-714.

Rachmawati, D., dan Susilawati, C. E. (2018). Relevansi Nilai Pengungkapan Modal Intelektual Secara Voluntary dan Involuntary (The Value Relevance of Intellectual Capital Voluntary and Involuntary Disclosures). Jurnal Akuntansi Dan Keuangan Indonesia, 15(2), 121-137. https://doi.org/10.21002/jaki.2018.07

Rachmawati, D., Rahayu, M., dan Wijaya, H. (2018). INTELLECTUAL CAPITAL AS FIRM VALUE PREDICTOR (EMPIRICAL STUDY ON INTELLECTUAL CAPITAL INDEX). International Conference on Business and Management Research.

Shella, dan Wedari, L. K. (2016). Intellectual Capital dan Intellectual Capital Disclosure Terhadap Market Performance pada Perusahaan Publik Indeks LQ-45. Jurnal Akuntansi \& Auditing Indonesia, 20(1), 27-36. https://doi.org/10.20885/jaai.vol20.iss1.a rt3

Sirojudin, G. A., dan Nazaruddin, I. (2014). Pengaruh Modal Intelektual dan Pengungkapannya Terhadap Nilai dan Kinerja Perusahaan. Jurnal Akuntansi Dan Investasi, 15(2), 77-89.

Sujoko, dan Soebiataro, U. (2007). Pengaruh Struktur Kepemilikan Saham, Leverage, Faktor Intern dan Faktor Ekstern Terhadap Nilai Perusahaan. Jurnal Manajemen Dan Kewirausahaan, 9(1), 41-48. 